early 1920s had demonstrated that a corneal graft would take only if there were a sufficiency of clear cornea in the eye of the recipient; a graft inserted into a bed of corneal scar tissue invariably turned opaque. In such a cornea Filatov inserted a clear lamellar graft and at a later stage inserted a penetrating graft for visual purposes.

In work such as this he noticed that the implantation of a graft tended to clear corneal opacities which might already be present. Upon this observation he built up a theory of the stimulation of tissues by the release of "biogenic substances", a theory which became a considerable cult in Russian medicine. With this as the theoretical basis, he launched a new method of therapy based on the injection, topically or systemically, of a vast number of animal and vegetable substances, the products of which were assumed to stimulate the tissues of the host, and for a time this method of "tissue therapy" was widely employed in the treatment of a host of degenerative ocular diseases which responded to no other therapy-myopic chorio-retinal atrophy, primary pigmentary degeneration of the retina, optic atrophy, and so on. The most common material ultimately employed was derived from the placenta which was used either as the injection of placental extract or the subconjunctival implantation of placental tissue. Most ophthalmologists are agreed that whatever the theoretical justification for this method of therapy, in practice it brought little or no benefit, and it has generally fallen completely out of use. However this may be, Filatov will always be remembered for his achievements in technical surgery and the originality of his concepts.

\title{
R. C. J. MEYER
}

Reinhard Carl Johannes Meyer, who died on November 7, 1956, in Johannesburg, was born in 1883 in Kimberley, Cape Province, South Africa. He was the son of a missionary, and was educated in Kimberley and in Cape Town, where he graduated B.A. in 1902. He was awarded the Jamieson Scholarship and took a medical training at Edinburgh University where he graduated M.B., Ch.B. in 1908.

He returned to South Africa to become house physician and house surgeon at the Johannesburg General Hospital from 1910 to 1912. In 1953 he returned to Europe for further studies, taking his M.D. and F.R.C.S. at Edinburgh, and his D.O. at Oxford.

After demobilization from World War I he became a house surgeon at Moorfields Eye Hospital (R.L.O.H.), and he returned to South Africa in the latter part of 1919 to begin practice as an ophthalmic surgeon in Johannesburg. He was appointed ophthalmic surgeon to the Transvaal Memorial Hospital for Children in 1923 and to the staff of the Johannesburg General Hospital in 1924, where he served for a first term of 15 years. He was recalled to the Johannesburg General Hospital for the years 1939-1945 during the absence of other senior ophthalmic surgeons on war service.

In 1930, together with the late Dr. Wood of Cape Town and Dr. Verwey of Pietermaritsburg, he was instrumental in forming the Ophthalmological Society of South Africa, of which he became President in the years 1938 and 1939.

He was one of the pioneers in South Africa of diathermy treatment for detachment in the early 1930s, of intra-capsular extractions of cataracts about the same time, and of corneal grafting in 1937.

He took a keen interest in the work of the Society to help the civilian blind in Johannesburg, and was associated from the inception with the St. John Ophthalmic Foundation which established an Eye Hospital on the outskirts of Johannesburg to begin work in 1951.

He was married in Bournemouth in 1916 to Phyllis Bagshaw who survives him, as do also his only daughter, and three sons who are members of the medical profession. 